\title{
A situational approach to the application of the inventory control theory to maintenance spares control
}

\author{
I.B. Hipkin \\ Department of Business Science, University of Cape Town, Rondebosch 7700, Republic of South Africa
}

Received 8 May 1991, accepted 7 August 1991

\begin{abstract}
The management of maintenance spares has frequently been treated as part of the management of the total inventory in production-oriented organizations. In this article it is suggested that maintenance spares should be grouped into four categories: non-stock, usage stock, project stock and insurance stock. Rather than using a common inventory control approach to all spares, different techniques should be applied to each category. Developments in reliability-centred maintenance will result in less reliance on forecasting maintenance spares requirements, thereby permitting a higher service level without an increase in inventory carrying costs.
\end{abstract}

Instandhoudingsonderdele word dikwels as deel van die algemene voorraad hanteer. In hierdie artikel word vier kategorieë instandhoudingsonderdele omskryf, naamlik: nie-gebruiksvoorraad, gebruiksvoorraad, projekvoorraad en versekeringsvoorraad. Verskillende beheerstelsels word vir elke kategorie voorgestel. Ontwikkelinge in betroubasrheidsgesentreerde instandhouding impliseer vermindere afhanklikheid van die voorspelling van instandhoudingsonderdele-vereistes. Dit sal aanleiding gee tot 'n groter mate van beskikbaarheid van voorraad sonder 'n verhoging in voorraadkoste.

\section{Introduction}

In many organizations traditional inventory control techniques have been applied to the management of maintenance spares. This is done in the genuine belief that such a spares control system will provide a high enough level of service to minimise downtime, and yet avoid overstocking. This will thereby achieve the aim of keeping spare parts to a minimum without causing loss of production arising from a lack of spare parts.

In this article I seek to provide a broad, situational approach to maintenance spares control. The intention is to analyse the general applicability of traditional inventory control techniques to the maintenance repair and operating supply (MRO) situation. It is first necessary to consider the distinct categories of maintenance spares and to assess the extent to which each class readily exhibits appropriate demand and other behavioural characteristics.

\section{Determining MRO inventorles}

The wide variety of maintenance activities is well known. These include the following functions: repair, modification, installation, moving and removing equipment, fabrication and preventive maintenance functions. The costs associated with these activities may be summarised as follows (Newman, 1985):

- cost of excessive maintenance

- cost of maintenance labour

- costs incurred by inefficient use of maintenance personnel

- cost of storage and maintenance of spares inventory

- price of 'close-enough-for-now' spare parts which may serve for the temporary situation but which will have to be replaced sooner than normal

- price of spares purchased or produced on an emergency basis

- cost of avoidable downtime

- opportunity loss of 'good' parts being scrapped.

With the exception of the first two items, and possibly the third, all of these costs are directly related to MRO in- ventories. Martin (in Higgins, 1988: 2-127) states that it is not uncommon for about half the dollar value of maintenance stores to be made up of spare parts'. The problems associated with these inventories are those of cost and control. Before we can understand the factors contributing to such costs, and how inventories can be controlled, it is useful to illustrate the wide diversity of MRO items. Bialous (1984) gives the following list of MRO items:

- common disposable spare parts, with replenishment through re-order from a supplier (for example, filters, bearings)

- disposable spare parts, with replenishment through incompany fabrication (for example, keys, shafts)

- spare parts which are repairable, with the repaired item being retumed as normal inventory

- critical spare parts, unique to a particular item of plant kept to prevent failure should the item in service fail

- critical spares requiring periodic testing to ensure that desired performance is always available

- maintenance shop items (such as channel iron, sheetmetal)

- maintenance supply items (such as welding rods, drill bits)

- manufacturing and general plant supply items (such as clothing, cleaning materials)

- tools and testing equipment

- parts and equipment for use on project or future maintenance work

- excess parts and equipment left over from other projects.

Since these items are all considered as maintenance spares, it is tempting to assume that their control should be based on the same principles. The first practical problem that arises is the greatly varying size and shape of parts and equipment; secondly, physical control in the manufacturing facility is aggravated by multiple storage locations; thirdly, the requirements for each category are often considered to be subject to uncontrollable factors.

Less tangible factors may present even greater problems. 
There is no bond of knowledge between the engineering department and the materials manager. The areas of conflict and mutual opinions of the other party are well known, but the problem lies in establishing functional areas of responsibility: the engineer is responsible for stipulating what should be held and he should estimate usage; the stores function performs all other apparently nebulous tasks such as part numbering and inventory control.

The widely differing types of maintenance spares support different activities such as emergency repairs, scheduled maintenance, projects and routine functions. The following categories can be identified in the context of an MRO inventory:

- non-stock

- usage stock

- project stock

- insurance stock

Handley comments on this categorisation as follows:

'By identifying material as belonging to one of these four groups and by using the appropriate inventory control techniques, you can gain more control over the inventory and maximise efficiency and economy. In order to do this you must understand both how these groups differ and the control technique associated with each' (1984: 36).

Before each category is discussed in more detail, it is necessary to address the issue of independent and dependent demand for inventory, and to discuss the traditional method of controlling MRO inventory: the economic order quantity (EOQ).

\section{Independent and dependent demand and the con- cept of EOQ}

The difference between independent and dependent demand is important because it suggests a situational approach to managing the MRO inventory system. An understanding of these two concepts is fundamental to an appreciation of the applicability of inventory control techniques.

\section{Independent demand}

The list of maintenance activities includes events which illustrate both independent and dependent demand. Independent demand refers to situations where detailed planning is not possible, such as random machine breakdown. In such instances, forecasting methods are used and they represent a preventive mode of operation. A common error when considering ordering spares whose demand is erratic is to concentrate solely on the quantity of spares required. Plossl seeks to counter this practice with the following principle:

'Correctly answering the question about when an item is needed is far more important than determining how much to order' (1985: 97).

A description of forecasting techniques is beyond the scope of this article, but it is as well to note that certain techniques (such as the running average method) are good for intermittent demand, but others (such as first and second order exponential smoothing) are poor.

The emphasis on controlling maintenance spares whose demand is independent tends to be on a fixed order quantity basis with a variable-cycle system. The amount to order for independent demand is calculated using the economic order quantity concept which has been identified as one of the basic elements in independent demand inventory management. The EOQ concept is widely (and sometimes erroneously and inappropriately) used in conventional inventory control situations in a production environment. This article makes no pretence at entering the EOQ debate, but, it should be pointed out that the first problem with the EOQ concept is the difficulty in calculating the input figures. Much has been written on what items should be included and which should be excluded from the two cost factors (ordering costs and inventory carrying costs).

With regard to ordering costs in a maintenance application, there are either the costs of placing purchasing orders to buy items from a supplier, or the costs associated with ordering a manufactured item from within the organisation. Typical costs for the latter include paperwork, machine set-up costs, and other once-off costs.

Inventory carrying costs must incorporate at least the following: obsolescence, deterioration, insurance, storage costs and capital.

While the EOQ appears to produce an elegantly precise solution, the questions must be asked: do companies really know these costs, and hence are the results meaningful?

The second problem relates to the applicability of the EOQ concept. As a general rule, the EOQ concept applies under the following conditions (Plossl, 1985):

- The item is replenished in lots or batches, either by purchasing or manufacturing, and is not produced continuously.

- Usage rates are uniform and are low compared to the rate at which the item is normally produced, so that a significant amount of inventory results.

The first condition is generally fulfilled for MRO spares; the second is often not.

There are several general situations where the EOQ concept is not suitable. One of these where the EOQ is totally inappropriate is where demand (quantity and timing) is specified. This is discussed in the maintenance context in the following section.

\section{Dependent demand}

When there are plans and schedules that are under the control of the maintenance engineer, the demand for spares is dependent on those plans and schedules. Since the quantity of spares and the time at which they will be required can be anticipated accurately, far greater precision in calculating spares requirements is possible than in the case of independent demand. The demand pattern can be cyclical or non-cyclical, depending on the schedule. The cyclical pattern is illustrated in Figure 1.

It can be seen that the re-order point is not quantity dependent, but time-dependent: the re-order point is determined by the lead time. Cyclical dependent demand for spares typically occurs in the case of annual shutdowns.

Non-cyclical dependent demand is a function of the failure mode of plant and equipment. The traditional failure 


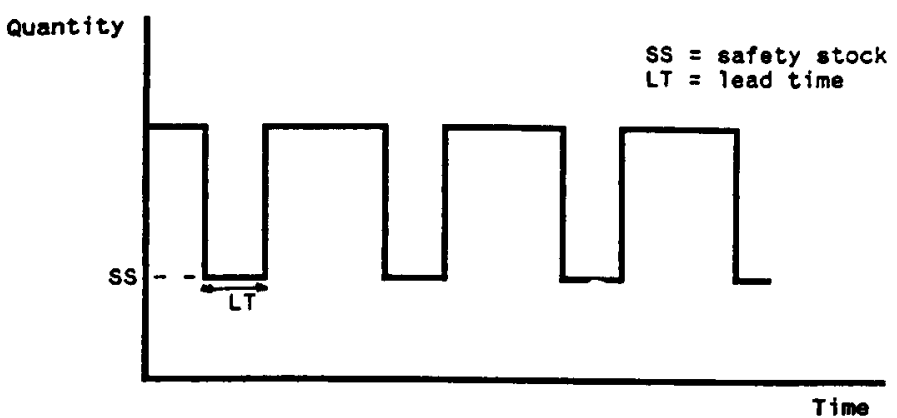

Flgure 1 Cyclical demand for spares

pattern is illustrated in Figure 2, indicating either an initial and subsequent random failure pattern or a high initial probability of failure (the settling-in or burn-in period) followed by a relatively constant probability of failure (random failure probability between $t 1$ and $t 2$ ). Since $t 2$ represents the point in time whereafter the failure probability increases, the curve in Figure 2 would indicate that maximum reliability will be obtained if replacement $\propto$ ccurs at time $\mathfrak{t}$. The failure pattern (with high infant mortality) is known as the 'bath tub' failure pattem. The dotted line indicates that some equipment does not exhibit the burn-in period. (A discussion of other failure patterns is beyond the scope of this article.)

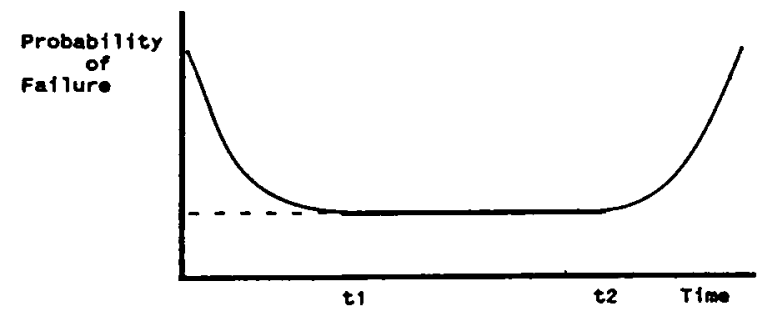

Figure 2 Traditional failure pattern

The problem lies in predicting time 12 , since this will then indicate when spares or replacements will be required. Reliability-centred maintenance theory proposes that for each failure mode one of four consequences will ensue:

- hidden consequences

- safety and/or environmental consequences

- operational consequences

- non-operational consequences

For each consequence one of three maintenance tasks may then be applicable and effective:

- an on-condition task

- a scheduled rework task

- a scheduled discard task

Should one of these three not be applicable and effective, then a failure-finding task is required for hidden failure consequences, some combination of tasks or a redesign is essential for safety and/or environmental consequences, and no scheduled maintenance is advisable for operational and non-operational tasks. Redesign may be desirable for hidden failures and the last two consequences.

The traditional failure pattern illustrated in Figure 2 indicates that the component has an age or a life at which it fails. In the case where the age of a component can be determined before there is a rapid increase on the pro- bability of failure, scheduled rework (overhaul) is recommended; when the life of the component can be estimated, scheduled discard and replacement of the component are applicable.

However, before the age or life of a component is sought, it is desirable to assess whether some on-condition task can be found to detect the advent of a failure. Some plant and equipment progress from a fully functional state to a failed state in a measurable period of time and in so doing, they give warning that they are about to fail. This time period can vary from months (in the case where oil particle analysis is used to detect imminent failure in bearings) to minutes or even seconds. The concept is illustrated in Figure 3 which depicts a measure of functional state on the vertical axis (100\% is fully functional and $0 \%$ is the failed state).

For any item of plant there is a condition at which the plant cannot function adequately: this condition is called a functional failure and the time at which this occurs is indicated as ' $f$ ' in Figure 3. The condition of functional failure is preceded by another condition called potential failure (the time at which this occurs is indicated as 'tp' in Figure 3). This is a condition which is less satisfactory than normal, where the impending failure is first detected. Performance of equipment is still adequate for acceptable functioning. The time between the potential failure and the functional failure (the warning interval) is the time during which action can be taken to prevent functional failure. In modern maintenance management, condition monitoring techniques are used to alert the engineer or operator before functional failure occurs. In this sense, the demand for maintenance spares can frequently be considered to be dependent demand provided the waming interval is as least as long as the lead time.

At this stage it is appropriate to return to the four categories of MRO inventory and to discuss which method of inventory control is best for each category.

\section{Categories of MRO Inventory}

Not only have incorrect inventory control techniques been applied to the MRO situation, but matters have been aggravated by erroneous perceptions of maintenance problems, especially in relation to equipment failures. The belief has been that preventive (or 'planned') maintenance provides a sure solution to maintenance problems: in other words, all components are perceived to have an age or a life, and fail according to the traditional view of equipment failure as shown in Figure 2.

When determining spares requirements, maintenance managers have sought to determine the economic impact of

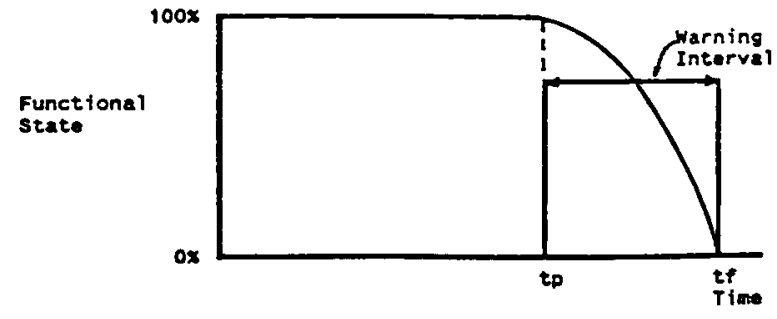

Figure 3 Failure process 
downtime; they have then identified the critical functions and equipment; then on this basis they have selected the spare parts to be used in their preventive maintenance programmes. The essence of spares procurement was often the EOQ concept, yet it will be shown that dependent demand lends itself to an MRP (Materials Requirements Planning) approach. This problem is best addressed by considering the four categories of maintenance spares.

\section{Non-stock}

Items not dedicated to a specific project nor designated as insurance stock will either be for continued, regular use, or for a once-off exercise. Records of past usage will assist in establishing whether the item is used regularly. If the item is deemed to be in continuous use, anticipated inventory levels must be set. The costs of holding the item as stock should be balanced against the corresponding costs associated with on-the-spot purchases. This will be the determining factor as to whether or not the item should be given a stock number. Ready availability from suppliers is obviously a further concern when deciding to designate an item as non-stock.

Handley states that:

'... the advantage of satisfying the demand of the MRO through non-stock is that there is no increase of inventory. In order to be sure that materials are being handled in the most efficient way ... the inventory control system (should) treat these non-stock items the same as the stock items, with the exception of prompting a re-order' (1984: 38).

The control of non-stock inventory is thus essentially the same as for stock items, and this will be discussed in the next section.

\section{Usage stock}

Usage spares are those for which there is an ongoing requirement in day-to-day maintenance operations. The pattem of aggregate demand for these items is not entirely predictable and can fluctuate. Such usage spares include wearing parts for plant and equipment, lubricants, consumables, and so on.

The demand for usage stock is independent demand which is predicted using forecasting techniques. Previous discussion indicated that the important issues are:

- when to order (given by re-order points [ROP])

- how much to order (given by re-order quantities)

- how much to order (purchasing practices)

The result should be the provision of an acceptable level of service to the maintenance department. (Service level is a measure of the number of stockouts on first request compared to the total demand for an item over a given period of time.)

The ordering process thus becomes the control mechanism for MRO usage spares. Regular feedback is essential for the correct assessment of safety stock levels. The justin-time philosophy should be heeded in that buffer stocks and work-in-progress are to be avoided. Setting comfortable safety stocks that will ensure plentiful supplies of all MRO stocks could well be construed as poor management practice. Tight control of inventory, particularly safety stocks, is essential. This is partly achieved by regular updates of stock levels, forecasts, lead times and orders.

The concept of a minimum order quantity (MOQ) takes into account stock-on-hand and on order, ROP, lead time and forecasts. The MOQ indicates to the inventory controller how much has to be ordered. The EOQ will minimise costs. Using these two figures, the controller must use his judgment to decide on the final order quantity. This decision will incorporate knowledge of changing demand patterns, storage facilities, and so on. Non-stock and usage items are thus controlled using the traditional EOQ theory and human judgment.

It is widely accepted that the economic order quantity is only a management tool. It cannot be prescriptive both because of the problems mentioned earlier, and also because of practical situations where common sense must prevail. Some of the practical considerations include:

- Die or tool life: costs associated with the limited life of a die or tool are not specifically taken into account in EOQ calculations. The EOQ for manufacturing a certain component may be 20 , but the die may have a useful life of 30 components. As there are frequently substantial costs involved in setting up a die, it would probably be sensible to increase the order quantity for the components to 30 .

- Shelf life: for those items with limited shelf life, smaller orders may be placed more frequently, even though the ordering costs may exceed the inventory holding costs.

- Storage implications: when applying the EOQ to usage spares, two factors need to be considered: can the quantity be accommodated in the available storage area; is the material handling capacity sufficient to handle the EOQ?

- Scrap allowances: it may be necessary to add an additional quantity to the computed order quantity of spares in order to compensate for normal scrap or loss in the maintenance process.

\section{Project stock}

MRO spares for project work are classified as dependent demand spares. Accurate planning is possible to a large extent, so the emphasis should lie in ensuring that spares arrive just before they are needed. An MRP, or even better, a just-in-time (JIT) approach should provide the best method of controlling project spares. Demand for project spares should not be satisfied out of stock.

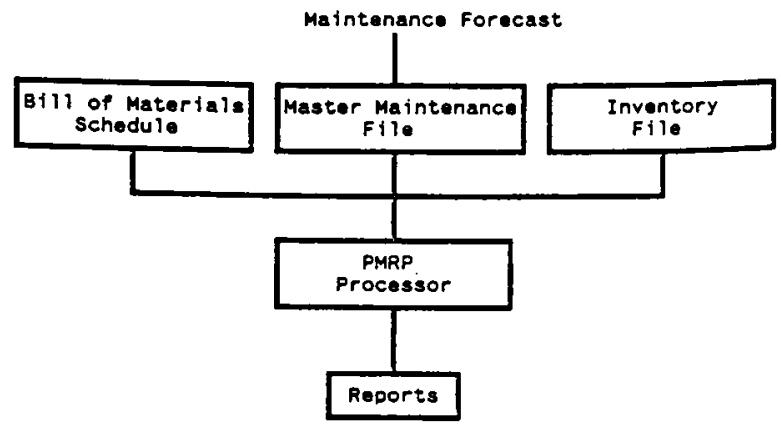

Figure 4 Schematic of preventive maintenance requirements planning 
In Figure 4 the elements of the MRP approach are given. The Master Maintenance Schedule (MMS) is the driving force behind the system. It will specify the work to be done, based on the following types of criteria:

- mean time between failures

- specific production output

- hours of operation

The MRP function takes each item of plant identified above and compiles the Bill of Materials (BOM). The replacement policy is applied to the BOM and this provides the spares needed for the project or overhaul.

The Preventive Maintenance Requirements Planning (PMRP) processor functions as the normal MRP processor by providing reports on what spares will be required and when.

Newman (1985) has identified several shortcomings in this approach:

- non-avoidable failures do occur which cause maintenance resources to be expended on an emergency basis;

- sometimes the depth of the work effort is not fully defined until the planned shutdown occurs. Failure is more expensive than first noted and replacement becomes more cost effective than repair or overhaul, and costs have been incurred in diagnosis; and

- parts may be substituted on a 'temporary' basis, and 'temporary' becomes permanent.

However, Newman does see some specific benefits from adopting the principles of MRP:

- parts consumption patterns and costs are easily tracked;

- high maintenance users are identified;

- better employment of maintenance personnel is made;

- downtime caused by lack of availability of spare parts is minimised;

- meaningful definitions of repair, rebuild and recondition are obtained;

- spares and repair parts inventory are likely to be reduced;

- 'temporary' substitutions are reduced;

- a move is made toward standardization of certain types of equipment; and

- top management is provided with an accurate cost overview of capital equipment costs and the positive impact of preventive maintenance activities.

\section{Insurance stock}

Insurance stock is held because of its deemed importance to the maintenance operation. Management identifies insurance items and specifies stock levels. Although demand is independent, the methods of inventory control described above are not suitable. Estimated usage, lead times and availability are significant factors that are used to set these stock levels, but of overriding importance is the economic impact of downtime. In order to reduce the tendency to overstock insurance items, the re-order point (ROP) is frequently set below the insurance stock level. The quantity ordered should be sufficient to bring the available balance back to the insurance level.

The basis of determining insurance stock (or critical spares) is that of assessing the economic impact of downtime. Calaway believes that this approach 'determines the risk which a company is taking by not stocking any particular spare part. The degree of risk is then used as a guide in making decisions on carrying spare parts' (1984: 24).

Following the determination of the economic impact of downtime, the critical functions and equipment are identified, and spare parts are selected. A detailed explanation of three steps is given in Calaway (1984).

\section{Other categorisations}

Another categorisation of spares is proposed by Ainosuke (in Nakajima, 1989). Two categories are discussed: permanent and non-permanent stocks. If usage can be estimated, the component should be categorised as non-permanent stock; if usage cannot be estimated, the component should be treated as permanent stock. Ainosuke (1989: 258) further maintains that the following items should be treated as permanent stock, irrespective of whether or not their usage can be estimated:

- parts for equipment which result in breakdowns when there is no back-up equipment

- parts that should be ordered three to four times per year

- parts likely to fail between maintenance periods

- replacement parts for emergency repairs

- parts with delivery times greater than planned service intervals.

Ainosuke (1989: 255) describes six methods of controlling permanent stocks:

- order point method

- double bin method

- package method (parts kept in packages, with loose parts used first, and an order is placed when a package is opened)

- batch issue method

- fixed quantity ordering method

- fixed interval ordering method

While this categorisation into permanent and non-permanent stocks, and the methods of controlling permanent stocks may be useful, Ainosuke's analysis does not specify what technique should be used under the different circumstances.

In fach, his permanent stock category would broadly fall under the heading of independent demand. However, his non-permanent category would need further classification for his analysis to be more rigorous.

\section{Conclusion}

This article has introduced the concept of a situational categorisation of maintenance repair and operating supply spares. This division is necessary to ensure that the appropriate methods of inventory control are applied to each category, rather than assuming that one single system of control can be applied throughout. The definite trend towards tightening controls of inventory makes this categorisation essential and presents management with some techniques that can be applied with confidence.

Developments in reliability-centred maintenance and further analyses of equipment failure patterns should mean that increasingly the demand for spares should shift from independent to dependent demand, thereby reducing the re- 
liance on forecasting and economic order quantities. Dependent demand for maintenance spares implies a just-intime approach to ordering, thereby increasing service levels while reducing stockholding costs.

\section{References}

Bialous, R. 1984. Inventory management for MRO spares. MRO Stores Seminar Proceedings - APICS, 1-13.

Calaway, L.P. 1984. An analytical approach for stocking critical spares. MRO Stores Seminar Proceedings - APICS, 20-26.
Handley, R.W. 1984. Controlling MRO inventories. MRO Stores Seminar Proceedings - APICS, 35-40.

Higgins, L.R. 1988. Maintenance engineering handbook. 4th Edition. New York: McGraw Hill, 1202p.

Nakajima, S. 1989. TPM development programme: Implementing TPM. 1st Edition. Cambridge: Productivity Press, 403p.

Newman, R.G. 1985. MRP where $M=$ preventive maintenance. Journal of SAPICS, Vol. 26, No. 2: 53-62.

Plossl, G.W. 1985. Production and inventory control. Englewood Cliffs, NJ: Prentice-Hall, 443p. 